

\title{
Carbonate precipitation in artificial soils as a sink for atmospheric carbon dioxide
}

P. Renforth ${ }^{1,2}$, D.A.C. Manning ${ }^{1,2}$ \& E. Lopez-Capel ${ }^{2,3}$

${ }^{1}$ Insitute for Research on Environment and Sustainability, Newcastle University, Newcastle upon Tyne, NE1 7RU, United Kingdom

${ }^{2}$ School of Civil Engineering and Geosciences, Newcastle University, Newcastle upon Tyne, NE1 7RU, United Kingdom

${ }^{3}$ Joseph Swan Institute for Energy Research, Newcastle University, Newcastle upon Tyne, NE1 7RU, United Kingdom

\begin{abstract}
Turnover of carbon in soils is the dominant flux in the global carbon cycle and is responsible for transporting 20 times the quantity of anthropogenic emissions each year. This paper investigates the potential for soils to be modified with calcium rich materials (e.g. demolition waste or basic slag) to capture some of the transferred carbon as geologically stable calcium carbonate. To test this principal, artificial soil known to contain calcium rich minerals (calcium silicates and portlandite) was analysed from two sites across North East England, UK. The results demonstrate an average carbon content of $30 \pm 15.3 \mathrm{Kg} \mathrm{C} \mathrm{m}^{-2}$ stored as calcium carbonate, which is three times the expected organic carbon content and has accumulated at a rate of $25 \pm 12.8 \mathrm{t} \mathrm{C} \mathrm{ha}^{-1} \mathrm{y}^{-1}$ since 1996. Isotopic analysis of the carbonates gave values between -6.4 and $-27.5 \%$ for $\delta^{13} \mathrm{C}$ and -3.92 and $-20.89 \%$ for $\delta^{18} \mathrm{O}$ respectively (against $\mathrm{V}$ PDB), which suggests that a combination of carbonate formation mechanisms are operating including the hydroxylation of gaseous $\mathrm{CO}_{2}$ in solution, the sequestration of degraded organic carbon with minor remobilisation/precipitation of lithogenic carbonates. This study implies that construction/development sites may be designed with a carbon capture function to sequester atmospheric carbon into the soil matrix with a maximum global potential of $290 \mathrm{Mt} \mathrm{C} \mathrm{y}^{-1}$.
\end{abstract}

Keywords: pedogenic carbonates, stable isotopes, inorganic carbon, urban soil

\section{Introduction}

The global carbon cycle transports approximately 210Gt of carbon (C) per year between a multitude of pools including the biosphere, geological sediment, the ocean and the atmosphere. During this cycle, $60 \%$ of all the carbon flux passes between the atmosphere and the terrestrial system (120GtCy ${ }^{-1}$; Dupre et al., 2003). Thus within the context of the possible use of geoengineering procedures to compensate for artificial $\mathrm{CO}_{2}$ emissions (e.g. Lal, 2003), it is highly appropriate to consider the role of the coupled plant-soil system in carbon capture, and to develop ways of enhancing natural processes artificially.

In temperate climates, the role of soils as carbon sinks is often associated with the accumulation of soil organic carbon (SOC) in agricultural soils (Smith et al., 2000). Documentation of soil inorganic carbon (SIC) is usually confined to soils formed in arid climates, where unbroken 'calcrete' structures can cover an area of several $\mathrm{km}^{2}$. Schlesinger (1985) suggests that soils of this type may contain between 24.5 and $33 \mathrm{~kg} \mathrm{C} \mathrm{m}^{-2}$.

Recent work has demonstrated substantial variability of organic carbon content in urban soils which can be as high as $28.5 \mathrm{~kg} \mathrm{C} \mathrm{m}^{-2}$, although the average carbon content is expected to be between 8 and $10 \mathrm{~kg} \mathrm{C} \mathrm{m} \mathrm{m}^{-2}$ (Pouyat et al., 2002, Pouyat et al., 2006, Banaitis et al., 2007). Pouyat et al. (2002) have demonstrated the influence of landuse on SOC and suggest that soils beneath impervious surfaces or in clean engineered fill material will return the lowest values for organic carbon. Moreover, the turnover of carbon in urban soils and the characterisation of the carbon pool (labile to refractory) have yet to be determined. By investigating the formation of inorganic carbon (SIC) as carbonate minerals, the aim of this study is to enhance our understanding of the carbon cycle in urban soils.

Soils at two brownfield sites in North East England, UK were investigated for the accumulation of SIC as geologically stable calcium carbonate $\left(\mathrm{CaCO}_{3}\right)$. Brownfield sites are commonly but not exclusively characterised by the presence of waste material arising from the historical use of the site, a proportion of which becomes part of the soil matrix. Some of this is derived from construction materials, including calcium-rich components (artificial mortars, plaster, concrete, slag; natural basic rock aggregates . (e.g. Fredericci et al., 2000)). It is hypothesised that weathering of calcium-rich minerals (silicates, hydroxides, sulphates) within these materials will result in precipitation of $\mathrm{CaCO}_{3}$ within soils through equation (1) by 
reaction with carbon cycled through plant roots (Manning, 2008).

$$
\mathrm{Ca}^{2+}+2 \mathrm{HCO}_{3}^{-} \leftrightarrow \mathrm{CaCO}_{3}+\mathrm{H}_{2} \mathrm{O}+\mathrm{CO}_{2}
$$

The availability of calcium depends on the stability of the calcium minerals in the soil system. The rate at which these materials weather and release calcium is dependant on various factors including mineralogy, physical grain properties (including surface area), solution $\mathrm{pH}$, the presence of organic complexes and flow rate, but is estimated to vary between $10^{-15}$ and $10^{-6} \mathrm{~mol} \mathrm{~cm}^{-2} \mathrm{~s}^{-1}$ (Blum and Stillings, 1995, Berg and Banwart, 2000, van Hees et al., 2002).

Carbon is transferred into the soil through dissolution in rainwater or through biological processes. During growth, plants exude large quantities of carbon through their roots as organic compounds which ultimately degrade to $\mathrm{CO}_{2}$ and return to the atmosphere (Kuzyakov and Domanski, 2000, Ryan et al., 2001). This is the dominant conveyor in the global carbon cycle, and transports approximately $120 \mathrm{GtCy}^{-1}$ compared to $6 \mathrm{GtCy}^{-1}$ produced by anthropogenic sources (Lal, 2003). The rate at which plants turnover carbon is difficult to measure, but Manning (2008) suggests between 1.2 and $16.1 \mathrm{mg} \mathrm{C}$ per gram of fresh weight per year is exuded from plant roots based on in-vitro experiments (Ryan et al., 2001). However, Moulton et al., (2000) have monitored the carbonate concentration of waters issuing from a groundwater system in Iceland, showing that plant-derived bicarbonate concentrations of waters draining forested areas were between 911 and $999 \mathrm{~mol} \mathrm{ha}^{-1} \mathrm{yr}^{-1}$, or approximately $500 \mathrm{~mol} \mathrm{~kg}^{-1} \mathrm{yr}^{-1}$ when normalised against biomass per ha (Manning, 2008). This is an order of magnitude larger than the exudation rates calculated from the laboratory experiments.

Carbon dating of pedogenic (soil formed) carbonates indicates long residence times in soils (>30,000 years; Kalin et al. (1997)) and field studies of carbonates in ancient soils similarly support refractory nature of carbonates(up to 2.6 billion years; e.g. Watanabe et al. 2004). Furthermore, Kuzyakov et al. (2006) demonstrated, in controlled conditions, the dissolution and reprecipitation of carbonate minerals under the influence of plant roots. They concluded that a $100 \%$ turnover of the carbonate can take between 400 and 2000 years. Both the field and laboratory scale investigations have demonstrated the stable nature of pedogenic carbonates on human time scales.
The aim of the research reported here is to investigate the extent to which soils modified by the artificial introduction of calcium minerals can capture carbon exuded from plants to give a semi-permanent sink, and the significance of this process as compensation for artificial carbon emissions.

\section{Study Sites}

An urban brownfield site was chosen in Newcastle upon Tyne approximately $2.5 \mathrm{~km}$ east of the city centre (GB National Grid: NZ275649 see insert of Fig 1) which was previously occupied by a concrete office complex that was demolished in 1996. The site has remained unused since then, apart from storage of a soil heap excavated from an adjacent development site (approximate location shown in Fig 1). A contaminated land report completed by Newcastle City Council in 1998 presented soil profiles that show the presence of demolition waste throughout the site to $2-3 \mathrm{~m}$ in depth. Furthermore, the study found $\mathrm{pH}$ levels of up to 11.8 and a sulphate content of up to $20313 \mathrm{mg}$ $\mathrm{kg}^{-1}$ towards the north of the site indicating portlandite $\left(\mathrm{Ca}(\mathrm{OH})_{2}\right)$ and gypsum $\left(\mathrm{CaSO}_{4} \cdot 2 \mathrm{H}_{2} \mathrm{O}\right)$ dissolution respectively. Vegetation on the site comprised of $\mathrm{C}_{3}$ grasses (including species typical of a restoration seed mix) and $\mathrm{C}_{4}$ ornamental garden escapes. The bedrock geology of the area is dominated by Carboniferous sandstone which is superficially overlain by glacial till. The site has been heavily modified by industrial activity and a substantial thickness $(>3 \mathrm{~m})$ of made ground is present.

A second site was selected adjacent to a former steel works in Consett (GB National Grid: NZ094492), County Durham, which was closed in the 1980s creating 290 ha of derelict land. Harber and Forth (2001) investigated soil contamination problems associated with iron and steel making at the site and highlight the use of lime, basic, rich slag as a filler and capping material (up to a depth of $45 \mathrm{~m}$ ) for soils contaminated with heavy metal. Subsequent analysis of the area (Mayes et al., 2006) has discovered $\mathrm{pH}$ levels within leachate of 12.5 draining the site which was attributed to the weathering of portlandite and calcium silicate minerals. The waters were supersaturated with respect to calcite and showed a relationship between precipitation and biological activity, coupled with attenuation of $\mathrm{pH}$ through a pond and calcareous wetland which has developed on a watercourse draining the former steel works area. A calcareous hardpan has formed at the surface adjacent to the pond and covers and 
area of approximately $400 \mathrm{~m}^{2}$. The bedrock geology of the area is dominated by the Carboniferous mudstones of the Lower Coal Measures, but the landscape has been considerably altered by industrial activity.

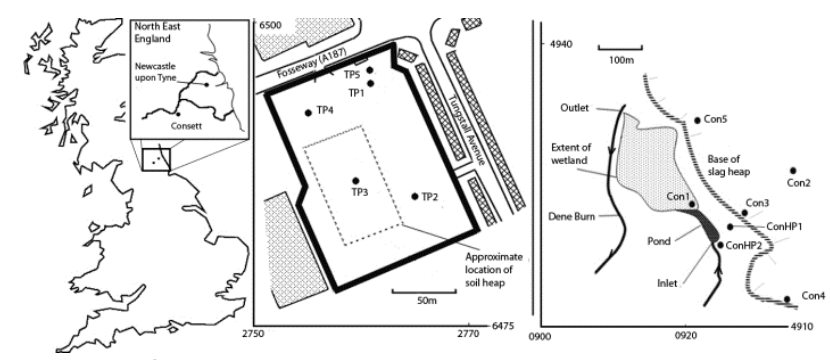

Fig 1. Sampling locations $(\bullet)$ at an urban brownfield site in Newcastle upon Tyne (left) and a former steelworks in Consett (right) (Grid based on the Ordinance Survey National Grid of Great Britain - tile NZ)

\section{Methodology}

At the brownfield site in Newcastle upon Tyne, Ian Farmer Associates (www.ianfarmerassociates.co.uk) were contracted to excavate 5 trial pits to $3.5 \mathrm{~m}$. At the former steelworks at Consett, soil samples were collected with a hand auger to depths up to $20 \mathrm{~cm}$ prior to contact with large fragments of slag. Furthermore, sediment was collected from the bottom of the high $\mathrm{pH}$ pond (locations are shown in Fig 1). Samples were collected through the soil profile at both sites, air-dried and sieved to <2 $\mathrm{mm}$. Calcium carbonate content was determined using an Eijkelkamp calcimeter to BS 7755$3.10: 1995$ (reproducibility better than $\pm 0.6 \%$ ), the residue was collected, washed, filtered and oven dried at $80^{\circ} \mathrm{C}$ and used for the determination of organic carbon isotope ratios. Soil $\mathrm{pH}$ was analysed according to ISO 10390 1994, using a Jenway $3020 \mathrm{pH}$ meter.

Isotope ratio mass spectrometry was conducted using a Europa Scientific 20-20 IRMS (Iso-Analytical, Cheshire UK) for ${ }^{13} \mathrm{C} /{ }^{12} \mathrm{C}$ and ${ }^{18} \mathrm{O} /{ }^{16} \mathrm{O}$ for calcium carbonate and ${ }^{13} \mathrm{C} /{ }^{12} \mathrm{C}$ for organic carbon collected from the calcimeter residues. Replication had a standard deviation better than $\pm 0.1 \%$ o and all but two of the 9 standards were within two standard deviations of the expected result. The results were recorded relative to the Vienna Peedee Belemnite scale (V-PDB).

\section{Results}

\subsection{Urban Brownfield, Newcastle upon Tyne}

In some trial pits, visible precipitates of calcium carbonate occurred as coatings and concretions on demolition rubble. Chemical analysis determined calcium carbonate quantities within the soil between 2.2 and 19.9 wt \% $(\bar{x}=$ $9.5 \% \mathrm{~s}=5.1)$. Trial pits TP1, TP4 and TP5 showed negative correlation with depth $\left(r^{2}=0.78\right.$, 0.99 and 0.50 respectively after removal of outliers from the basal clay in TP1, which a carbonate content of $4.3 \%$ was measured compared with values between $11 \%$ and $20 \%$ returned for other samples from the same trial pit, and unconsolidated sand in TP5, which had a similar lower value than the other samples from the same pit). There was no variation in carbonate content with depth in TP2 and TP3 (see Fig 2 - note error bars are within the data point symbols).

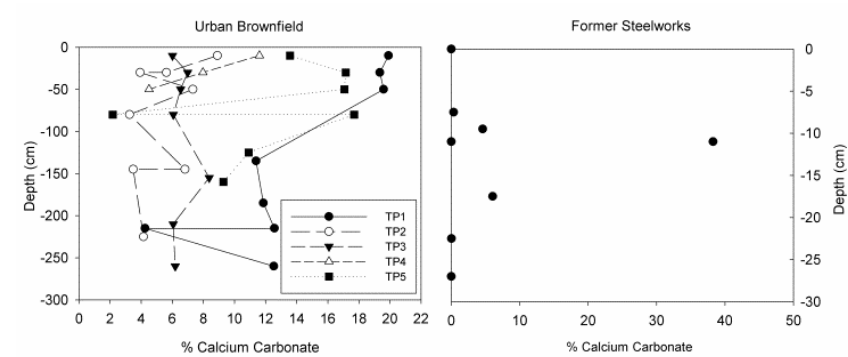

Fig 2. Carbonate concentrations with depth at both sites

Carbon and oxygen isotope analysis of the carbonates gave $\delta^{13} \mathrm{C}$ values between $-6.3 \%$ and $-27.5 \%$ and $\delta^{18} \mathrm{O}$ between $-3.9 \%$ and $-20.9 \%$ (Fig 3). The most negative carbonate isotope values (between -13.3\% and $-27.5 \%$ ) were detected in precipitates on demolition rubble. There is a positive correlation between oxygen and carbon inorganic isotope values $\left(r^{2}=0.66\right.$ or 0.86 after the removal of outliers). Analysis of the organic carbon isotope ratios gave values between $-19.0 \%$ and $-24.0 \%{ }^{13} \mathrm{C}$ (all but one value lies within 1 standard deviation of the mean of $22.9 \%$ ).

Comparison of $\mathrm{pH}$ values recorded in this study with those presented in the contaminated land report suggest a decline in soil pH over time (from 12 to 7 at the present day). However, a comparison is speculative due to variation in sampling sites.

\subsection{Former Steelworks, Consett}

Calcium carbonate occurred in both the soil (pedogenic carbonate) and within the drainage system of the site (tufaceous carbonate). Quantities of $\mathrm{CaCO}_{3}$ ranged between $0 \%$ and $93.4 \%(\bar{x}=29.6 \% \mathrm{~s}=36.6)$ over both systems. The largest concentration of $\mathrm{CaCO}_{3}$ was recorded in the sediment of the pond (>90\%) and the hardpan (48-87\%). The concentration of pedogenic carbonate was extremely variable 
(between $0 \%$ and $38.3 \%-\bar{x}=7.0 \% \mathrm{~S}=14.0$ ) and there appears to be no relationship between concentration and depth (see Fig 2) Carbonate isotope ratios were between $-17.6 \%$ and $-22.7 \%$ for $\delta^{13} \mathrm{C}$ and $-11.3 \%$ and $-16.1 \%$ for $\delta^{18} \mathrm{O}$ (see Table 1 and Fig 3)

Table 1. Isotopic values and sample depth for pedogenic carbonates at both sites

\begin{tabular}{lccc}
\hline Sample No & $\begin{array}{c}\text { Sample } \\
\text { depth } \\
(\mathrm{cm})\end{array}$ & $\delta^{13} \mathrm{C}$ & $\delta^{18} \mathrm{O}$ \\
\multicolumn{4}{c}{} \\
Urban Brownfield $($ NZ275649) \\
A2TP1 1 & $0-20$ & -7.7 & -8.6 \\
A2TP1 2 & $40-60$ & -20.2 & -13.1 \\
A2TP1 3 & $200-230$ & -18.6 & -11.7 \\
A2TP2 1 & $0-20$ & -15.1 & -12.0 \\
A2TP2 2 & $40-60$ & -10.7 & -10.1 \\
A2TP2 3 & $200-250$ & -7.9 & -8.5 \\
A2TP3 1 & $0-20$ & -6.7 & -8.5 \\
A2TP3 2 & $40-60$ & -6.4 & -9.1 \\
A2TP3 3 & $190-230$ & -7.4 & -8.6 \\
A2TP4 1 & $0-20$ & -8.5 & -7.9 \\
A2TP4 2 & $40-60$ & -15.0 & -9.5 \\
A2TP5 1 & $0-20$ & -16.2 & -10.8 \\
A2TP5 2 & $40-60$ & -20.1 & -12.3 \\
A2TP5 3 & $150-170$ & -17.1 & -11.1 \\
A2TP1 RS 1 & $100-170$ & -27.5 & -20.9 \\
A2TP1 RS 2 & $170-200$ & -23.0 & -14.2 \\
A2TP2 RS 1 & $200-250$ & -21.0 & -12.8 \\
A2TP2 RS 2 & $100-190$ & -13.3 & -3.9 \\
A2TP5 RS 1 & $40-60$ & -18.9 & -13.9 \\
& & & \\
Former Steelworks $(N Z 094492)$ & & \\
CON 01 1 & $0-35$ & -22.1 & -14.2 \\
CON 01 2 & Surface & -22.7 & -16.1 \\
CON 04 1 & $0-19$ & -17.6 & -11.3 \\
CON HP1 1 & $0-8$ & -22.1 & -15.5 \\
CON HP1 2 & $8-15$ & -18.2 & -11.8 \\
CON HP2 1 & $>15$ & -20.3 & -13.3 \\
CON HP2 2 & $0-15$ & -21.8 & -15.5 \\
\hline
\end{tabular}

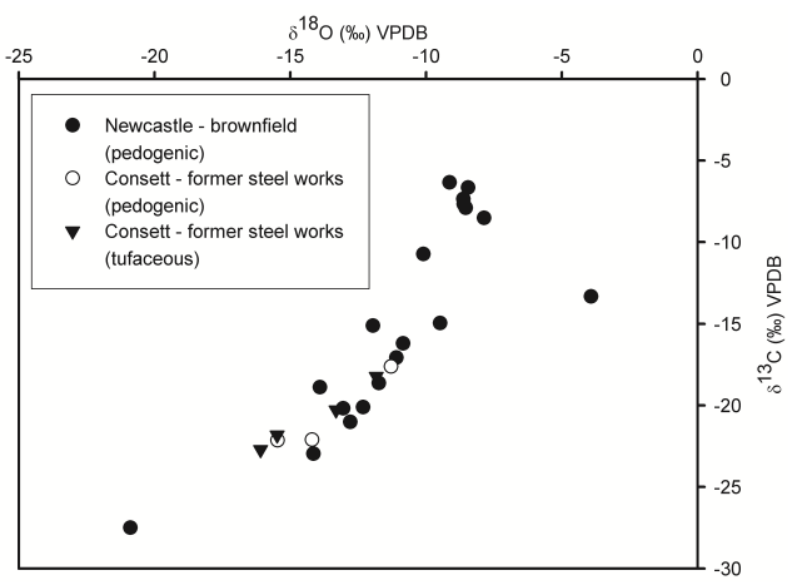

Fig 3. Isotopic ratios from carbonates formed in an urban brownfield soil $(\bullet)$ and within the drainage regime of the former steelworks (०).

\section{Discussion}

5.1 $\quad \delta^{13} \mathrm{C}$ and $\delta^{18} \mathrm{O}$ Stable Isotopes of Carbon

Stable isotope analysis has been used to study carbonates since the 1950s (Craig, 1953) primarily to investigate diagenesis conditions in limestone and the influence of organic carbon during the remobilisation of calcium carbonate in soils (Hudson, 1977). Early work by Solomans and Mook (1976) and Cerling (1984) demonstrate the incorporation of organic carbon in pedogenic carbonates which characteristically have isotopic values between $-2 \%$ and $-10 \%$ for $\delta^{13} \mathrm{C}$ and $0 \%$ and $-5 \%$ for $\delta^{18} \mathrm{O}$ respectively. Similar values have been found in more recent studies from a range of environments. It is clear that carbonate isotope values are controlled by precipitation conditions, including climate, rainfall, temperature, underlying geology and continentality (Andrews, 2006). The data obtained for the artificial soils investigated here are compared with published data from both natural and artificial soil in Fig 4 and Fig 5.

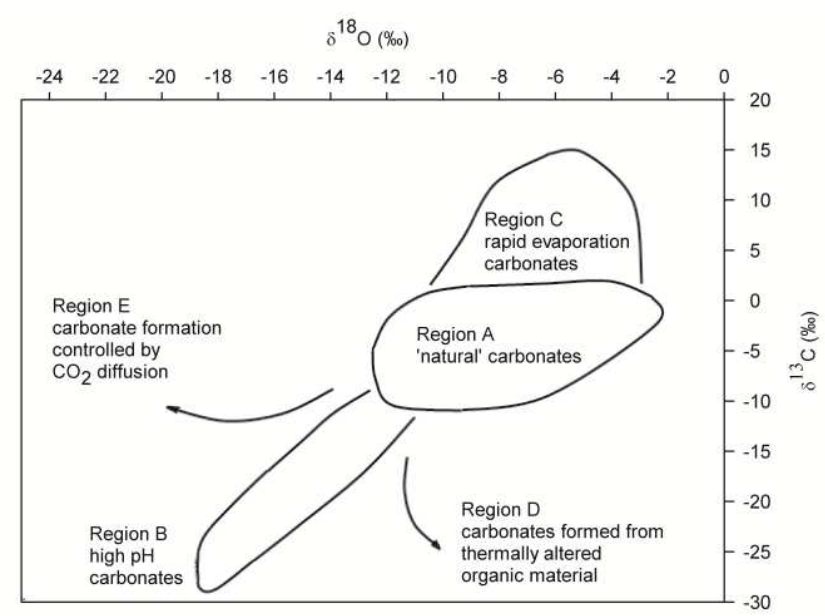

Fig 4. $\delta^{13} \mathrm{C}$ and $\delta^{18} \mathrm{O}$ isotope values returned from carbonates formed in a range of environments. Region A depicts carbonates formed in 'natural' conditions (Salomons and Mook, 1976, Cerling, 1984, Liu et al., 1996, Zanchetta et al., 2000, Knauth et al., 2003, Piovano et al., 2004, Bajnoczi et al., 2005, Boguckyj et al., 2006, Kovda et al., 2006, Sinha et al., 2006, Singh et al., 2007, Wang and Greenberg, 2007, Sikes and Ashley, 2007, Łącka et al., 2008, Yanes et al., 2008). Region B depicts the range of values returned from carbonates in high pH environments (Macleod et al., 1991, Andrews et al., 1997, Krishnamurthy et al., 2003, Boguckyj et al., 2006, and Fléhoc et al., 2006). Region $C$ depicts values returned from 
evaporation dominated environments (Achyuthan et al., 2007, Knauth et al., 2003). Region D includes values from carbonates which have been formed under the influence of thermally modified organic carbon (Ohlsson, 2000, and Fourcade et al., 2007). Region E depicts carbonates formed under closed/semi closed systems where the diffusion of $\mathrm{CO} 2$ becomes rate limiting (Van Strydonck et al., 1989, and Kosednar-Legenstein et al., 2008).

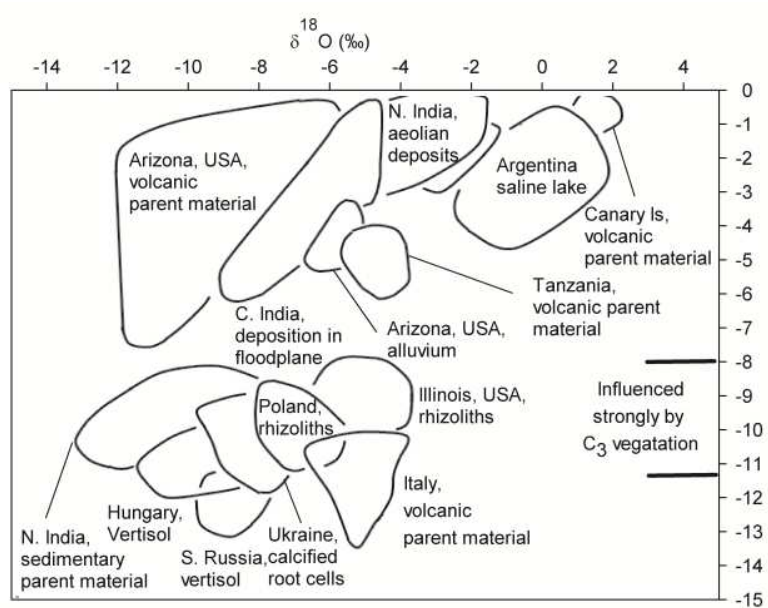

Fig 5. Detailed breakdown of isotope values in Region A.

In Figure 4, Region A represents the precipitation of carbonates in 'natural' sedimentary environments. In Figure 5, the expected range of $\square^{13} \mathrm{C}$ values is shown for carbonates formed under the influence of $\mathrm{C} 3$ vegetation. Several studies fall within this range (Salomons and Mook, 1976, Cerling, 1984, Zanchetta et al., 2000, Bajnoczi et al., 2005, Kovda et al., 2006, Boguckyj et al., 2006, Wang and Greenberg, 2007, Singh et al., 2007, and Łącka et al., 2008). According to Andrews (2006) there is a general decrease in $\delta^{18} \mathrm{O}$ with increasing continentality (from $\delta^{18} \mathrm{O}=-4 \%$ o to 14\%o). Many authors (Boguckyj et al. 2006; Singh et al. 2007; Wang and Greenberg, 2007; Lacka et al. 2008) record the occurrence of rhizoliths, which are carbonates formed within close proximity to plant roots and are dominated by organic carbon.

The provenance of carbon within pedogenic carbonates is usually a combination of that which is derived from organic carbon, and remobilisation of lithogenic carbonates. Pedogenic carbonates formed under these influences will return an isotopic signature which is between the organically-dominated region and the lithogenically-dominated region contiguous with $\delta^{13} \mathrm{C}=0 \%$ (Hudson, 1977). However, the use of isotope ratio data to determine host geology is potentially ambiguous, demonstrated by Zanchetta et al. (2000), Sikes and Ashley (2007) and Yanes et al. (2008), who have independently found differing values for carbonates formed in soils on igneous parent rocks.

Several studies have published isotopic data for carbonates formed in anthropogenic environments (Region B in Fig 4). Macleod et al. (1991), Deitzel et al. (1992) and Krishnamuthy et al. (2003) have investigated the formation of carbonates in alkaline environments associated with concrete and attribute the observed negative isotopic signatures to kinetic fractionation when $\mathrm{CO}_{2}$ gas is dissolved in solution, which rapidly reacts with hydroxide ions (from portlandite dissolution) to form carbonate through equation 2.

$\mathrm{OH}^{-}+\mathrm{CO}_{2} \leftrightarrow \mathrm{CO}_{3}^{-}+\mathrm{H}^{+}$

The rate of this is governed by equation 3 (Dietzel et al., 1992):

$\mathrm{r}=\mathrm{C}_{\mathrm{o}} \cdot\left(\mathrm{D} \cdot \mathrm{k} \cdot\left[\mathrm{OH}^{-}\right]\right)^{0.5}$

where $k$ is the rate constant $\left(\mathrm{cm}^{3} \mathrm{~mol}^{-1} \mathrm{~s}^{-1}\right)$ for hydroxylation, $\mathrm{D}$ is the diffusion coefficient of $\mathrm{CO}_{2}$ through the liquid $\left(\mathrm{cm}^{2} \mathrm{~s}^{-1}\right)$ and $\mathrm{C}_{0}$ the $\mathrm{CO}_{2}$ concentration in solution $\left(\mathrm{mol} \mathrm{cm} \mathrm{cm}^{-3}\right)$. Assuming typical values for $k$ and $D$ of $10^{-4.83} \mathrm{~cm}^{2} \mathrm{~s}^{-1}$ and $10^{6.41} \mathrm{~cm}^{3} \mathrm{~mol}^{-1} \mathrm{~s}^{-1}$ respectively, it can be seen that the primary rate controlling step is the reaction between hydroxide and dissolved $\mathrm{CO}_{2}$ gas. Deitzel et al. (1992) have associated this phenomenon with an isotope fractionation of $18.8 \%$ for $\delta^{13} \mathrm{C}$, and a similar fractionation is experienced by oxygen isotopes. Further to this, Andrews et al. (1997), Boguckyi et al. (2006) and Flehoc et al. (2006) have published data which conform to this model. Collectively, the isotopic signatures observed in this study fall within a tight regression $\left(r^{2}=91.8 \%\right)$ against the line $\delta^{13} \mathrm{C}$ $=1.6 \delta^{18} \mathrm{O}+2.8$, which corresponds to carbonates formed in a combination of natural and high $\mathrm{pH}$ conditions. Indeed, the position on this line in comparison to the two approximate end members $\left(\delta^{18} \mathrm{O}=-6.75 \%\right.$, $\delta^{13} \mathrm{C}=-8 \%$ ) for organically derived carbon (Cerling, 1984) and $\left(\delta^{18} \mathrm{O}=-17.6 \%\right.$ o, $\delta^{13} \mathrm{C}=-25.3 \%$ ) for high $\mathrm{pH}$ carbonate (Dietzel et al., 1992), can be used to estimate the proportions of carbon derived organically and that which has been sequestered through hydroxylation.

Results from the isotopic analysis carried out in this study suggest that three mechanisms of 
carbonate formation (lithogenic remobilisation, hydroxylation of gaseous $\mathrm{CO}_{2}$ and organic carbon sequestration) were operating in the urban brownfield site and two (hydroxylation and organic carbon sequestration) were operating at the former steelworks. The relative proportions of each process can be deduced from proximity to each end member, as described previously, and is summarised in Fig 6. The recorded isotope values at both sites comply with the trend observed for other published data, and there is no statistical difference between slopes $(p<0.05)$. Remobilisation of lithogenic carbonate was assumed to be negligible in high $\mathrm{pH}$ waters.

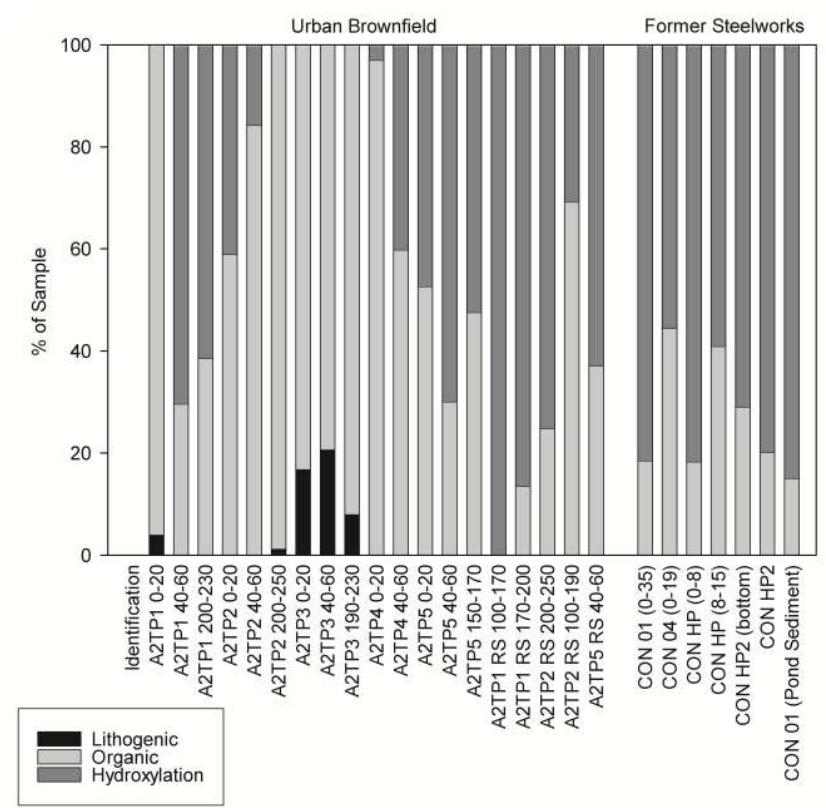

Fig 6. Proportions of carbonate precipitation mechanisms active at both study sites

\subsection{Carbonate precipitation in soil modified with demolition rubble}

The analysis of the urban brownfield site suggests that an average of $56.8 \%$ of the carbonate carbon is derived from organic origins, $40.5 \%$ is derived from hydroxylation and $2.7 \%$ from lithogenic carbonate. Extending these figures spatially for $10 \%$ average carbonate accumulation to $2.5 \mathrm{~m}$ depth and assuming $1 \mathrm{t} \mathrm{m}^{-3}$ density of crushed concrete (Dhir et al., 1999), it can be theorised that this particular urban brownfield site has a SIC content of $30 \pm 15.3 \mathrm{~kg}$ $\mathrm{C} \mathrm{m}^{-2}, 97.3 \%$ of which has been sequestered ultimately from the atmosphere. The SIC content is three times greater than the value reported for the average organic carbon content in urban areas (Pouyat et al., 2006). Extrapolating these figures through the life of the brownfield site, it can be estimated that the soil has accumulated carbon at a rate of approximately $25 \pm 12.8 \mathrm{t} \mathrm{C}$ ha $^{-1} \mathrm{y}^{-1}$. It can be speculated that the accumulation of carbonate is accordingly matched by a decrease in soil $\mathrm{pH}$. Indeed, the $\mathrm{pH}$ levels recorded in both this study and the contaminated land report completed in 1998 were not sufficiently high to cause hydroxylation. Therefore, it can be hypothesised that the accumulation of hydroxylated carbonate was rapid (within two years) and the subsequent carbonate accumulation is the result of calcium silicate weathering and organic carbon sequestration. However, the clast-supported nature of the soil suggests that the site drains freely; therefore, it is possible that the microenvironment around individual soil grains experience high $\mathrm{pH}$ levels.

\subsection{Carbonate precipitation in soil modified with basic slag}

Similar analysis of the carbonate carbon formed within soil modified with basic slag suggests that $31.4 \%$ of the carbonate carbon is derived from organic carbon and $68.6 \%$ is the product of hydroxylation of soil $\mathrm{CO}_{2}$. Carbonate concentration is heterogeneous throughout the site and is clearly dependent on the drainage regime, with high concentrations at the pond/wetland and lower concentration at the brow of the slope. High $\mathrm{pH}$ levels are still present within the drainage waters on site almost 30 years after the steelworks were closed, which suggests sustained weathering of portlandite.

The rate of carbonate formation within the aqueous regime at the former steelworks was calculated by Mayes et al (2006) using the Dreybrodt limestone tablet method. They found that precipitation rates decrease across the flow path of the wetland between $0.6 \mathrm{t} \mathrm{C} \mathrm{ha}^{-1}$ year $^{-1}$ and $1.8 \mathrm{t} \mathrm{C} \mathrm{ha}^{-1}$ year $^{-1}$ over an area of $1500 \mathrm{~m}^{2}$. The high variability of soil carbonate concentration means that it is not possible to carry out spatial accumulation calculations.

\subsection{Implications for carbon capture and geoengineering}

Brownfield sites are ubiquitous in the UK as a consequence of the country's industrial heritage, and cover approximately 42,000 ha of land (see Table 2 for details). Extrapolating $30 \mathrm{~kg} \mathrm{C} \mathrm{m}^{-2}$ for carbonate concentration found in this study, it can be estimated that the UK stores approximately $12.5 \mathrm{Mt} \mathrm{C}$ as carbonate in brownfield soil. It is interesting to speculate the carbon capture potential of urban soils if they were designed for that purpose. For example, the 625 ha occupied by London Olympics 2012 by our calculations could sequester 180,000 t C. 
The formation of calcium carbonate within soils by reaction with construction materials is one way to compensate for the production of $\mathrm{CO}_{2}$ during cement manufacture. Given the importance of concrete in construction (an industry which contributes $8 \%$ of the UK economy; DBERR, 2008), a full understanding of the possible value of concrete as a carbon sink at the end of its life allows the full life cycle impact of carbon emissions associated with construction to be understood in the context of sustainably mitigating climate change.

The maximum capacity of inorganic carbon capture technology is limited by the availability of calcium-rich minerals. DCLG (2007) suggests approximately $88.6 \mathrm{Mt}$ of construction and demolition waste is produced annually in the UK and $46.5 \mathrm{Mt}$ of this is currently landfilled or spread on demolition sites. Assuming a $\mathrm{CaO}$ content of $20 \%$, the maximum potential of carbonate capture is estimated to be $2 \mathrm{Mt} \mathrm{C} \mathrm{y}^{-1}$. These figures can be extrapolated to the global 'geoengineering' scale, under the assumption of a global production to waste ratio for concrete similar to the UK, and suggest that the upper limit for carbon capture using this technology is approximately $290 \mathrm{Mt} \mathrm{C} \mathrm{y}^{-1}$ which is equivalent to $90 \%$ of the emissions associated with cement manufacture (Hendriks et al., 2004).

Table 2. UK national and global limits of inorganic carbon capture technology

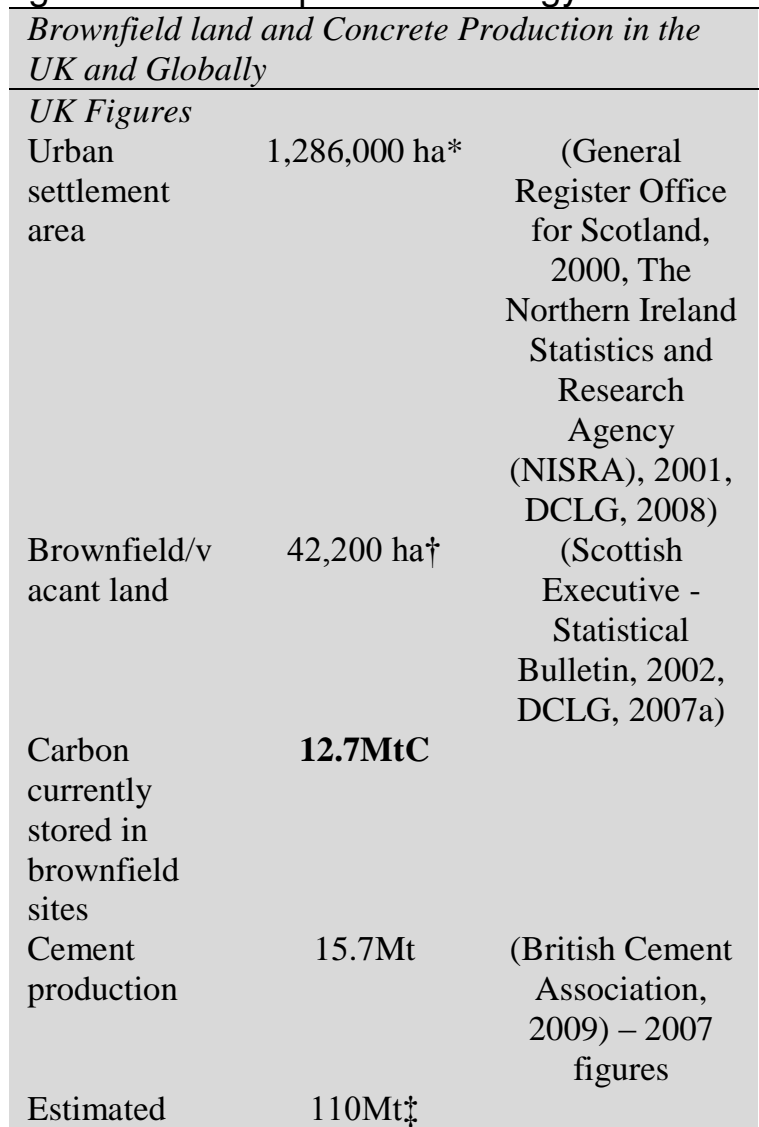

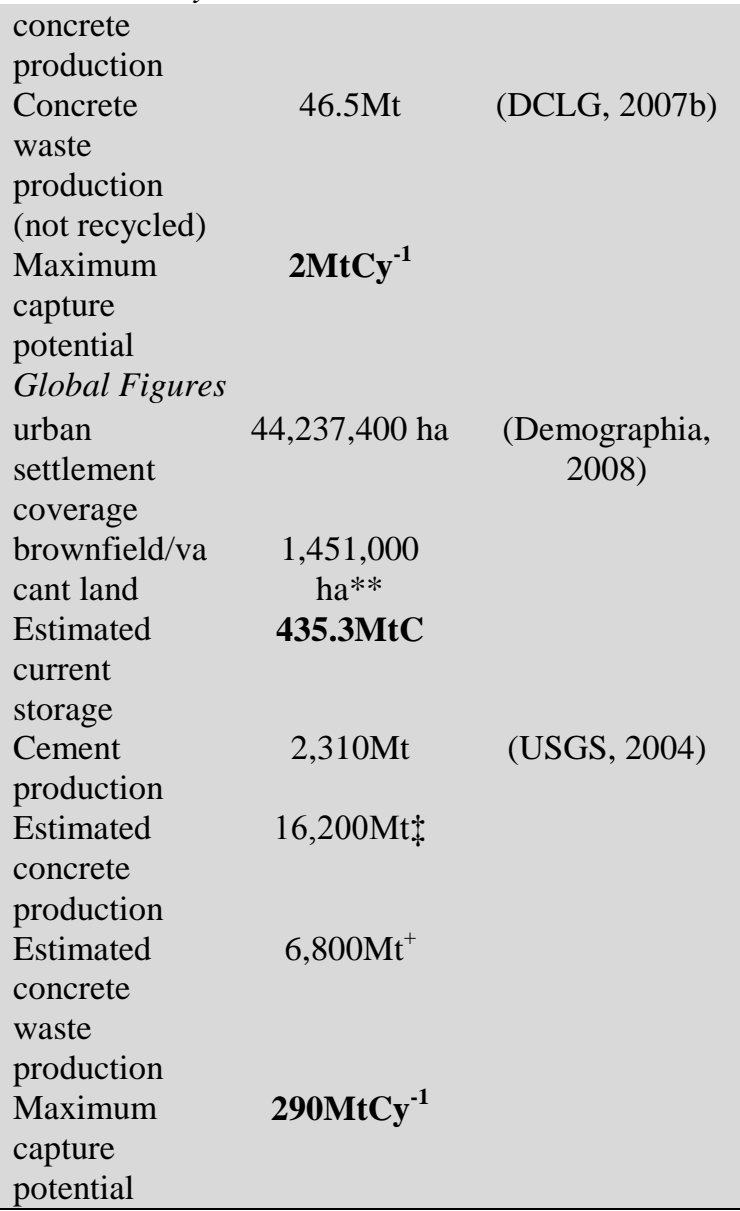

\section{Conclusion}

It is believed that this is the first reported case that demonstrates how artificial soils (i.e. made ground) can act as carbon sinks by accumulating calcium carbonate. Precipitation of calcium carbonate was found to be associated with the weathering of portlandite at both sites, but it is unknown to what extent other calcium rich minerals (calcium silicates, gypsum) are responsible for the formation of calcium carbonate. The capacity for the $\mathrm{OH}^{-}$ion to buffer $\mathrm{pH}$ in soil at the urban brownfield site has diminished over time as a result of hydroxylation of gaseous $\mathrm{CO}_{2}$, biological activity and site hydrology, which facilitated a decrease in soil $\mathrm{pH}$. It is possible that a similar $\mathrm{pH}$ regime is progressing at the former steelworks site but a larger initial concentration of portlandite has sustained the process. With this in mind, the prevalence of hydroxylation on site will be replaced by the incorporation of biologically influenced carbonates as the weathered cations from silicates exert greater influence on the precipitation of $\mathrm{CaCO}_{3}$. To that extent, further research should be undertaken to investigate the weathering and contribution of silicate minerals on carbonate formation. It is also important to note that the study area at the former steelworks is only a small fraction of the original site and it is 
impossible to gauge the efficiency of carbon capture without additional work to quantify the extent of the calcium rich material using extensive groundwater/hydrological analysis and soil profile analysis.

Brownfield soils are extremely heterogeneous and additional studies are required to investigate how other artificial soils accumulate carbon. The results of this study suggest that demolition waste recycled into the soil will sequester carbon at a rate of $25 \pm 12.8 \mathrm{t} \mathrm{C} \mathrm{ha}^{-1} \mathrm{y}^{-1}$. However, additional work is required to investigate carbonate dynamics and stability over time. Furthermore, investigations are needed to ascertain the carbon capture potential of soils specifically engineered for that purpose.

Decoupling economic development with the production of greenhouse gases is the most important step in sustainably mitigating climate change. Economically developed countries support a strong construction sector which is a direct physical manifestation of development. One of the primary materials of construction is cementious products (i.e. concrete), which is produced by calcining calcium carbonate and is responsible for $8 \%$ of the world's $\mathrm{CO}_{2}$ emissions (Wilson, 1993) and steel which is responsible for approximately 5\% (von Scheele, 2006). Reforming calcium carbonate in soils would partially close the loop on the carbon footprint from steel and cement production and decouple a substantial part of the construction industry from greenhouse gas emission.

\section{Acknowledgements}

This work was funded by ESPRC (EP/F02777X/1) and NERC (studentship NE/F008716/1). The authors would like to thank Philip Hartley and Newcastle City Council for providing information and access to one of the field sites. Dr Simon Peacock and Dr William Mayes at Newcastle University should also be thanked for their help during fieldwork. Comments from Professor Julian Andrews and an anonymous reviewer were appreciated.

\section{References}

Andrews, J. E. (2006) 'Palaeoclimatic records from stable isotopes in riverine tufas: Synthesis and review', Earth-Science Reviews, 75, (1-4), pp. 85-104.

Andrews, J. E., Gare, S. G. and Dennis, P. F. (1997) 'Unusual isotopic phenomena in Welsh quarry water and carbonate crusts', Terra Nova, 9, (2), pp. 67-70.

Bajnoczi, B., Horvath, Z., Demeny, A. and Mindszenty, A. (2005) 8th Isotope
Workshop of the European-Society-forIsotope-Research. Leipzig, Germany, Jun 25-30.Taylor \& Francis Ltd.

Banaitis, M. R., Langley-Turnbaugh, S. J. and Aboueissa, A. (2007) 'Variations of soil organic carbon in three urban parks: $A$ maine case study', International Journal of Applied Environmental Sciences, 2, (2), pp. 119-128.

Berg, A. and Banwart, S. A. (2000) 'Carbon dioxide mediated dissolution of $\mathrm{Ca}$ feldspar: implications for silicate weathering', Chemical Geology, 163, (14), pp. 25-42.

Blum, A. E. and Stillings, L. L. (1995) 'Feldspar Dissolution Kinetics', in White, A. F., Brantley, S. L. (ed), Chemical weathering rates of silicate minerals. Vol. 31 Mineralogical Society of America.

Boguckyj, A. B., Lanczont, M., Lacka, B., Madeyska, T. and Zawidzki, P. (2006) 'Stable isotopic composition of carbonates in Quaternary sediments of the Skala Podil'ska sequence (Ukraine)', Quaternary International, 152-153, pp. 313.

Cerling, T. E. (1984) 'The stable isotopic composition of modern soil carbonate and its relationship to climate', Earth and Planetary Science Letters, 71, (2), pp. 229-240.

Craig, H. (1953) 'The geochemistry of the stable carbon isotopes', Geochimica et Cosmochimica Acta, 3, pp. 53-92.

DBERR. (2008) Strategy for sustainable construction. Crown Copyright

DCLG. (2007) Survey of Arisings and Use of Alternatives to Primary Aggregates in England, 2005 Construction, Demolition and Excavation Waste. Crown Copyright

Dhir, R. K., Limbachiya, M. C. and Leelawat, T. (1999) 'Suitability of recycled concrete aggregate for use in BS 5328 designated mixes', Proceedings of the Institution of Civil Engineers-Structures and Buildings, 134, (3), pp. 257-274.

Dietzel, M., Usdowski, E. and Hoefs, J. (1992) 'Chemical and 13C/12C- and 18O/16Oisotope evolution of alkaline drainage waters and the precipitation of calcite', Applied Geochemistry, 7, (2), pp. 177184.

Fléhoc, C., Girard, J. P., Piantone, P. and Bodénan, F. (2006) 'Stable isotope evidence for the atmospheric origin of $\mathrm{CO} 2$ involved in carbonation of MSWI 
bottom ash', Applied Geochemistry, 21, (12), pp. 2037-2048.

Fredericci, C., Zanotto, E. D. and Ziemath, E. C. (2000) 'Crystallization mechanism and properties of a blast furnace slag glass', Journal of non-crystalline solids 273, pp. 64-75.

Harber, A. J. and Forth, R. A. (2001) 'The contamination of former iron and steel works sites', Environmental Geology, 40, (3), pp. 324-330.

Hendriks, C., Worrell, E., deJager, D., Blok, K. and Riemer, P. (2004) 'Emission Reduction of Greenhouse Gases from the Cement Industry', greenhouse gas control technologies conference. 23/08/2004. Emission Reduction of Greenhouse Gases from the Cement Industry: International Energy Agency, pp.

Hudson, J. D. (1977) 'Stable isotopes and limestone lithification', in:

Kalin, R. M., G. Dardis and J. Lowndes. (1997) 'Secondary Carbonates in the Antrim Basalts: Geochemical Weathering at 35KyBP', Geofluids II Conference Extended Abstracts, pp. 22-25.

Kovda, I., Mora, C. I. and Wilding, L. P. (2006) 'Stable isotope compositions of pedogenic carbonates and soil organic matter in a temperate climate Vertisol with gilgai, southern Russia', Geoderma, 136, (1-2), pp. 423-435.

Krishnamurthy, R. V., Schmitt, D., Atekwana, E. A. and Baskaran, M. (2003) 'Isotopic investigations of carbonate growth on concrete structures', Applied Geochemistry, 18, (3), pp. 435-444.

Kuzyakov, Y. and Domanski, G. (2000) 'Carbon input by plants into the soil - review', Journal of Plant Nutrition and Soil Science, 163, pp. 421-431.

Kuzyakov, Y., Shevtzova, E. and Pustovoytov, K. (2006) 'Carbonate re-crystallization in soil revealed by C-14 labelling: Experiment, model and significance for paleoenvironmental reconstructions', Geoderma, 131, (1-2), pp. 45-58.

Łącka, B., Łanczont, M., Komar, M. and Madeyska, T. (2008) 'Stable isotope composition of carbonates in loess at the carpathian margin (SE Poland) ', Studia Quaternaria, 25, pp. 3-21.

Lal, R. (2003) 'Global Potential of Soil Carbon Sequestration to Mitigate the Greenhouse Effect', Critical Reviews in Plant Sciences, 22, pp. 151-184.
Macleod, G., Fallick, A. E. and Hall, A. J. (1991) 'The mechanism of carbonate growth on concrete structures, as elucidated by carbon and oxygen isotope analyses', Chemical Geology, 86, (4), pp. 335-343.

Manning, D. A. C. (2008) 'Biological enhancement of soil carbonate precipitation: passive removal of atmospheric CO2', Mineralogical Magazine, in press.

Mayes, W. M., Younger, P. L. and Aumonier, J. (2006) 'Buffering of alkaline steel slag leachate across a natural wetland', Environmental Science \& Technology, 40, (4), pp. 1237-1243.

Moulton, K. L., West, J. and Berner, R. A. (2000) 'Solute flux and mineral mass balance approaches to the quantification of plant effects on silicate weathering', American Journal of Science, 300, (7), pp. 539-570.

Pouyat, R., Groffman, P., Yesilonis, I. and Hernandez, L. (2002) 'Soil carbon pools and fluxes in urban ecosystems', Environmental Pollution, 116, (Supplement 1), pp. S107-S118.

Pouyat, R. V., Yesilonis, I. D. and Nowak, D. J. (2006) 'Carbon Storage by Urban Soils in the United States', J Environmental Quality, 35, (4), pp. 1566-1575.

Ryan, P. R., Delhaize, E. and Jones, D. L. (2001) 'Function and mechanism of organic anion exudation from plant roots', Annual Review of Plant Physiology and Plant Molecular Biology, 52, pp. 527-560.

Salomons, W. and Mook, W. G. (1976) 'Isotope geochemistry of carbonate dissolution and re-precipitation in soils', Soil Science, 122, (1), pp. 15-24.

Schlesinger, W. H. (1985) 'The formation of caliche in soils of the Mojave-desert, California', Geochimica Et Cosmochimica Acta, 49, (1), pp. 57-66.

Sikes, N. E. and Ashley, G. M. (2007) 'Stable isotopes of pedogenic carbonates as indicators of paleoecology in the PlioPleistocene (upper Bed I), western margin of the Olduvai Basin, Tanzania', Journal of Human Evolution, 53, (5), pp. 574-594.

Singh, B. P., II Lee, Y., Pawar, J. S. and Charak, R. S. (2007) 'Biogenic features in calcretes developed on mudstone: Examples from Paleogene sequences of the Himalaya, India', Sedimentary Geology, 201, (1-2), pp. 149-156.

van Hees, P. A. W., Lundstrom, U. S. and Morth, C. M. (2002) 'Dissolution of microcline 
and labradorite in a forest $\mathrm{O}$ horizon extract: the effect of naturally occurring organic acids', Chemical Geology, 189, (3-4), pp. 199-211.

von Scheele, J. (2006) 'Short-term opportunities for decreasing $\mathrm{CO} 2$ emissions from the steel industry', International Journal of Green Energy, 3, (2), pp. 139-148.

Wang, H. and Greenberg, S. E. (2007) 'Reconstructing the response of $\mathrm{C}_{-}$and $\mathrm{C}_{4}$ plants to decadal-scale climate change during the late Pleistocene in southern Illinois using isotopic analyses of calcified rootlets', Quaternary Research, 67, (1), pp. 136-142.

Watanabe, Y., Stewart, B. W. and Ohmoto, H. (2004) 'Organic- and carbonate-rich soil formation 2.6 billion years ago at Schagen, East Transvaal district, South Africa', Geochimica et Cosmochimica Acta, 68, (9), pp. 2129-2151.

Wilson, A. (1993) 'Cement and concrete: environmental considerations', Environmental Building News.

Yanes, Y., Delgado, A., Castillo, C., Alonso, M. R., Ibáñez, M., De la Nuez, J. and Kowalewski, M. (2008) 'Stable isotope ([delta]18O, [delta]13C, and [delta]D) signatures of recent terrestrial communities from a low-latitude, oceanic setting: Endemic land snails, plants, rain, and carbonate sediments from the eastern Canary Islands', Chemical Geology, 249, (3-4), pp. 377-392.

Zanchetta, G., Vito, M. D., Fallick, A. E. and Sulpizio, R. (2000) 'Stable isotopes of pedogenic carbonates from the SommaVesuvius area, southern Italy, over the past 18 kyr: palaeoclimatic implications', Journal of Quaternary Science, 15, (8), pp. 813-824. 